\title{
PERBANDINGAN PENGGUNAAN MODEL PEMBELAJARAN \\ NUMBERED HEAD TOGETHER (NHT) DENGAN MODEL SNOWBALL THROWING TERHADAP KETERAMPILAN MENULIS TEKS PUISI SISWA KELAS VIII SMP N 1 SUNGAI BEREMAS
}

\author{
Nuzul Kurniati, Upit Yulianti DN, Titiek Fujita Yusandra \\ Program Studi Pendidikan Bahasa dan Sastra Indonesia STKIP PGRI Sumatera Barat \\ nuzulkurniati31@gmail.com
}

\begin{abstract}
This research is motivated by the problem that students are still less skilled in writing poetry texts. This type of quantitative research with experimental models. The research sample was students VIII/40 SMP N1 Sungai Beremas (20/experiment 1 and 20/experiment 2). The research data was in the form of poetry text writing skill scores using the Numbered Head Together (NHT) model and the Snowball Throwing model for the eighth grade students of SMP N 1 Sungai Beremas. The results of this study can be considered as follows. First, the skill level of writing poetry text for VIII grade students of SMP N 1 Sungai Beremas using the Numbered Head Together (NHT) learning model obtained an average score of 60.83 with sufficient qualifications. Second, the skill level of writing poetry text of the eighth grade students of SMP N1 Sungai Beremas using the Snowball Throwing learning model with an average score of 70 with sufficient qualifications (LdC). Third, from the results of hypothesis testing that the alternative hypothesis (H1) is accepted at a significant level of $95 \%$ and $\mathrm{dk}=\mathrm{n} 1+$ n2-2 because tcount $>$ ttable (2.15> 1.66). In other words, there is a significant comparison between the use of the Numbered Head Together and Snowball Throwing learning models on the skills written by grade VIII students of SMP N1 Sungai Beremas.
\end{abstract}

Keywords: Numbered Head Together (NHT), Snowball Throwing (ST), Poetry Text.

\section{PENDAHULUAN}

Pembelajaran bahasa Indonesia lisan/tulisan. Teks pada pembelajaran pada kurikulum 2013 menekankan bahasa Indonesia beragam jenis, pemahaman siswa terhadap berbagai digunakan untuk menyatakan suatu macam teks. Dalam pembelajaran kegiatan serta tujuan yang hendak Bahasa Indonesia, peranan teks dicapai. Dari keragamanteks yang ada sangatlah penting karena diterapkan terdapat menulis teks puisi. sebagai ungkapan kegiatan secara 
Menulis ialah kegiatan kreatif dalam pencapaian tujuannya. Hal ini juga diungkapkan oleh Dalman (2015:3), kegiatan komunikasi berupa penyampaian pesan (informasi) secara tertulis kepada pihak lain menggunakan bahasa tulis sebagai alat medianya. Aktivitasmenulis melibatkan beberapa unsur, yaitu penulis sebagai penyampai pesan, isi tulisan, saluran atau media, dan pembaca.

Menulis teks puisi terdapat dalam Kurikulum 2013 kelas VIII/I (KI).4 "Mencoba, mengolah, dan menyaji dalam ranah konkret (menggunakan, mengurai, merangkai, memodifikasi, dan membuat) dan ranah abstrak (menulis, menghitung, menggambar dan mengarang) sesuai dengan yang dipelajari di sekolah dan sumber lain yang sama dalam sudut pandang/teori”. Selanjutnya dijabarkan (KD)ke-4.8 "Menyajikan gagasan, perasaan, dan pendapat dalam bentuk teks puisi secaratulis/lisan dengan memperhatikan unsur-unsur pembangun puisi”.

Atmazaki (1991:4) menjelaskan bahwa puisi adalah karangan yang terkait baris, bait, rima,irama,jumlah kata dan suku kata.
Berdasarkan hasil wawancara 08 Maret 2020 dengan guru Bahasa Indonesia SMP N 1 Sungai Beremas, Aiyatul Kurniawan, S.Pd. diperoleh informasi sebagai berikut, Pertama, kemampuam siswa dalam menulis masih kurang terampil, karena siswa lebih suka pelajaran membaca. Kedua, siswa kurang terampil dalam menulis teks puisi, karena siswa belum memahami unsur-unsur pembangun yang ada pada teks puisi. Ketiga, siswa kurang berminat dalam menulis puisi, karena siswa sulit untuk menuangkan perasaanya kedalam bentuk puisi.

Selain melakukan wawancara dengan guru, wawancara juga dilakukan dengan sepuluh orang/siswa, siswa perlu bimbingan serta arahan untuk menulis teks puisi sebagai berikut. Pertama, tidak memahami unsur-unsur puisi. Kedua, kurangnya pengetahuan/sumber belajar.Ketiga, tidak bisa merangkai kata/mengeluarkan ide yang akan ditulis kedalam puisi.

Berdasarkan permasalahan yang diungkapkan oleh guru dan siswa, maka perlu diterapkan model (NHT) dan (ST). MenurutSohimin (2016:107), (NHT)merupakan model pembelajaran 
berkelompok yang setiap anggota kelompoknya bertangung jawab atas tugas kelompoknya sehingga tidak ada pemisahan antara siswayang satu dan siswa yang lain dalam satu kelompok untuk saling memberi dan menerima. Sedangkan Huda (2014:226)ST merupakan pembelajaran yang diadopsi pertama dari game fisik dimana segumpalan salju dilempar dengan maksud memukul orang lain.

Agar dapat meningkatkan keterampilan siswa, salah satu usaha yang dilakukan yaitu memakai model itu, karena kedua model ini melatih siswa dengan sistem belajar kelompok, dimana di dalam belajar kelompok ini siswa diberikan tugas sesuai dengan kemampuan secara individu, dan nantinya pengetahuan mereka akan disatukan dan disimpulkan secara kelompok tersebut.

\section{METODE PENELITIAN}

Jenis penelitia kuantitatif. Sugiyono (2014:23), dilakukan untuk meneliti populasi atau sampel. Data dikumpulkan menggunakan instrumen penelitian dengan metode eksperimen jenis quasi.
Populasi dalam penelitianya adalah kelas VIII SMP N 1 Sungai Beremas yang terdaftar berjumlahkan siswa 131 orang yang tersebar pada enam kelas. Pemilihan sampel secara potposie sampling, VIII-5\&6 dengan40 orang.

Instrumen penelitian tesunjuk kerja. Teknik pengumpulan data dilakukan 4 tahap, 2/eksperimen 1, dan 2/eksperimen II.

Tahap Pertama. Hari pertama dikela seksperimen I (NHT) sebagai berikut. Pertama, siswa dibagi kedalam kelompok. guru membagi siswaduduk perkelompok, guru menjelaskan tujuan pembelajaran sesuai dengan KI dan KD dan menyampaikan meteri tentang teks puisi. Kedua, setelah mereka duduk perkelompok, guru membagikan nomor ke masing-masing siswa untuk membedakan kelompok. Nomor yang dibagikan berbeda-beda setiap kelompok. Ketiga, guru mengaikan tugas kepada siswa yang berkakitan dengan unsur-unsur pembangun pada puisi, setelah itu menjawab pertanyaan guru dan menuliskan jawabanya kedalam bentuk menulis teks pusi dengan tema "Ibu". Keempat, setiap kelompok mulai berdiskusi jawaban yang telah mereka tulis dan 
mennentukan unsur pembangun teks puisi. Kelima, guru memanggil nomor dan yang telah dipilih tersebut untuk maju kedepan kelas. Untuk menampilkan hasil diskusinya. Keenam, siswa yang nomornya dipanggil menyampaikan hasil mereka dan yang lain ya menanggapinya sesuai dengan unsur pembangun teks puisi.

Hari kedua masih dikelas eksperimen I yaitu melakukan tes, dengan cara. Pertama, guru memberi siswa tugas menulis teks puisi bertema "Guru". Kedua, guru mengumpulkan pekerjaansiswadan diperiksa sesuai dengan indikator yang telah ditetapkan

Tahap kedua. Hariketiga eksperimen II dengan(ST) sebagai berikut. Pertama, Guru menyapa siswa, lalu guru melakukan apersepsi. Guru menjelaskan tujuan pembelajaran KI dan KD tentang menulis teks puisi. Guru menjelaskan amateri tentang teks puisi. Kedua, guru membentuk berberapa kelompokdan memanggil ketua menjelaskan materi tentang puisi.Ketiga, ketua kembali kekelompok mendiskusikan materi. Keempat, guru memberikan selembar kertas agar bertanya mengenai teks puisi. Kelima, kertas pertanyaan dibuat berbentuk bola. Lalu masing-masing kelompok melemparkan bola tersebut kekelompok laian dalam waktu kurang lebih 15 menit. Keenam, yang mendapatkan kertas bola maka diamenjawab pertanyaan tersebut. Selanjutnya siswa untuk menulis puisi dengan bertema“"Ibu”.Ketujuh, melakukan avaluasi terhadap materi yang telah dipelajari mengenai teks puisi.

Pada pertemuan keempat pada kelas eksperimen II sebagai berikut. Pertama, guru memberi tugas kepada siswa menulis puisi dengan tema "Guru". Kedua, tugas dikumpuldan diperiksa sesuai dengan indikator yang telah ditetapkan.

Setelah data dikumpulkan maka dilanjutkan dengan teknik anlisis data yang dimulai dari penskoran, penilaian serta melakukan uji analisis data normalitas,homogenitas, hipotesis,meny impulkan hasil.

\section{HASIL DAN PEMBAHASAN}

Penelitian ini dilaksanakan di SMP N1 Sungai Beremas.Pada tanggal 11 Agustus 2020 menulis teks puisi dengan model (NHT)/Eksperimen 1 20 orang. 13 Agustus2020 menulis teks 
puisi menggunakan model Snowball

Trhrowing 20 orang. Hasil dan pembahasan dapat dilihat sebagai berikut ini.

1. Keterampilan Menulis Teks Puisi dengan Menggunakan Model Pembelajaran Numbered Head Together (NHT) Siswa kelas VIII SMP N 1 Sungai Beremas

\section{Pemerolehannilaiketerampilan} menulis menggunakan (NHT) adalah 33,33-83,33. Secara lengkap, memperoleh nilai 33,33/1orang. memperoleh nilai 41,67/3orang. memeproleh nilai 50/2orang. memperoleh nilai 58,33/4orang. memperoleh nilai 66,67/5orang, memperoleh nilai 75/3orang. memperoleh nilai 83,33/2orang.

Tabel 1. Distribusi Frekuensi Keterampilan Menulis Teks Puisi Dengan Menggunakan Model Pembelajaran Numbered Head Together (NHT) Siswa Kelas VIII SMP N 1 Sungai Beremas Secara Umum

\begin{tabular}{cccc}
\hline No & X & F & FX \\
\hline 1 & 33,33 & 1 & 33,33 \\
2 & 41,67 & 3 & 125,01 \\
3 & 50 & 2 & 100 \\
4 & 58,33 & 4 & 233,32 \\
5 & 66,67 & 5 & 333,35 \\
6 & 75 & 3 & 225
\end{tabular}

\begin{tabular}{cccc}
7 & 83,33 & 2 & 166,66 \\
\hline & Jumlah & 20 & 1216,67
\end{tabular}

Berdasarkan data di atasdiperoleh (M) sebesar 60,83. Maka disimpulkan bahwa tingkat penguasaan Keterampilan menggunakan model 56$65 \%$ berkualifikas cukup (C).

2. Keterampilan Menulis Teks Puisi Dengan Menggunakan Model Pembelajaran Snowball Throwing Siswa Kelas VIII SMPN1 Sungai Beremas Pemerolehan nilai keterampilan menulis dengan menggunakan model Snowball Throwing adalah 50-91,67. Secara lengkap, memperoleh nilai 50/3orang, memperoleh nilai 58,33/2orang, memeproleh nilai 66,67/5orang. memperoleh nilai 75/5orang. memperoleh nilai 83,33/4 orang. memperoleh nilai 91,67/1orang.

Tabel 2. Distribusi Frekuensi Keterampilan Menulis Teks Puisi Dengan Menggunakan Model Pembelajaran Snowball Throwing Siswa Kelas VIII SMPN 1 Sungai Beremas Secara Umum

\begin{tabular}{cccc}
\hline No & X & F & FX \\
\hline 1 & 50 & 3 & 150 \\
2 & 58,33 & 2 & 116,66
\end{tabular}




\begin{tabular}{cccc}
3 & 66,67 & 5 & 333,35 \\
4 & 75 & 5 & 375 \\
5 & 83,33 & 4 & 333,32 \\
6 & 91,67 & 1 & 91,67 \\
\hline \multicolumn{2}{r}{ Jumlah } & 20 & 1400 \\
\hline
\end{tabular}

Berdasarkan nilai diata maka diperoleh rata-rata hitung 70. Maka disimpulkan bahwa tingkat penguasaan Keterampilan menggunakan model 66$75 \%$ berkualifikas lebih dari cukup.

3. Perbandingan Model

Pembelajaran Numbered Head Together (NHT)dengan Snowball Throwing terhadapmenulis Teks Puisi Siswa Kelas VIII SMP N 1 Sungai Beremas.

Perbandingan yang signifikan penggunaan kedua model memperoleht $_{\text {hitung }}(2,15)>t_{\text {tabel }}(1,66)$, sehingga hipotesis alternatif diterima.

Dengan demikian penggunaan model pembelajaran Snowbal Throwing dalam pembelajaran lebih baik. Maka dari itu siswa harus mampu meningkatkan kemampuan menulis agar dapat menghasilkan puisi yang baik dan sesuai dengan penggunaan bahasa dan unsur puisi yang benar. Maka dari penelitian ini terlihat peningkatan keahlian melalui penggunaan model pemebelajaran menarik dan inovatif.

Hal ini terbukti dari nilai ratarata hitung keterampilan menganalisis teks puisi dengan menggunkan Numbered Head Together (NHT) dikualifikasikan lebih dari cukup 60,83. Artinya siswa belum memahami materi dengan baik. Sedangkan, nilai rata-rata hitung keterampilan menganalisis teks puisi dengan menggunakan Snowbal Throwing dikualifikasikan baik rata-rata 70 .

Berdasarkan penelitian Indah. (2018), Perbandingan Penggunaan Media Audio Visual dengan Media Gambar Berseri terhadap Kemampuan Menulis Naskah Drama Siswa Kelas VIII SMP Negeri 1 Ranah Pesisir Kabupaten Pesisir Selatan”. Berdasarkan uji hipotesis $t_{\text {hitung }}>t_{\text {tabel }}$ $(3,07>1,70)$, maka dengan demikian terdapat perbandingan penggunaan media audio visual dengan mengunakan media gambar bersri terhadap kemampuan menulis naskah drama siswa kelas VIII SMP Negeri1 Ranah Pesisir. Penelitian memiliki persamaam dan perbedaan, persamaanya yaitu sama-sama melihat 
perbandingan penggunaan model yang dilakukan dalam satu kelas yang sama.

\section{KESIMPULAN}

Berdasarkan analisis data dan pembahasan didapatkan lah tiga hal berikut ini. Pertama, menggunakan model pembelajaran Numbered Head Together (NHT) memperoleh nilai 60,83 berada pada rentang $56-65 \%$ dengan kualifikasi yaitu cukup. Kedua, menggunakan model pembelajaran Snowball Throwing memperolehnilai 70 berada pada rentang $66-75 \%$ dengan kualifikasi yaitu lebih dari cukup (LdC).

Ketiga, dapat dilihat bahwa terdapat perbandingan pengunaan kedua model terhadap keterampilan menulis siswa puisi siswa, hal ini terlihat hipotesis $\left(\mathrm{H}_{1}\right)$ diterima signifikan $95 \%$ dan $(2,15>1,66)$. Dengan demikian, terdapat perbedan yang disignifikan antara penggunaan kedua model meningkatkan keterampilan menulis teks puisi siswa kelas VIII SMP N1 Sungai Beremas.

\section{DAFTAR PUSTAKA}

Atmazaki. 1991. Analisis Sajak Teori, Metodologi dan Aplikasi. Bandung: Angkasa Raya.

Cahyani, Apri Winar. 2016. Eksperimentasi Model Pembelajaran Kooperatif Tipe Numbered Heads Together (NHT) Dan Problem Based Learning (PBL) Dengan Pendekatan Saintifik Pada Materi Operasi Aljabar Ditinjau Dari Gaya Belajar Siswa SMP Kelas VIII Di Kabupaten Karanganyar Tahun Pelajaran 2014/2015. Jurnal Elektronik Pembelajaran Matematika ISSN: 23391685Vol.4, No.4.

Dalman. 2015. Keterampilan Menulis. Jakarta: PT Rajagrafindo Persada.

Huda, Muftahul. 2014. Model-model Pengajaran dan Pembelajaran. Yogyakarta: Pustaka Pembelajaran

Pradopo. 2007. Pengkajian Puisi. Yogyakarta:Gajah Mada University Press.

Shoimin. 2016. 68 Model Pembelajaran Inovatif Dalam Kurikulum 2013. Yogyakarta: ArRuzz Media.

Sugiyono. 2014. Metode Penelitian Kuantitatif dan Kualitatif dan $R \& D$. Bandung: Alfabeta, CV.

Tarigan, H. G. 2008. Menulis Sebagai Suatu Keterampilan Berbahasa. Bandung: Angkasa. 
Waluyo, Herman J. 2005. Teori Apresiasi Puisi. Jakarta: Gran Media Pustaka Utama. 